\title{
Duplicated insertion mutation in the microtubule-associated protein Spag5 (astrin/MAP126) and defective proliferation of immature Sertoli cells in rat hypogonadic (hgn/hgn) testes
}

\author{
Hiroetsu Suzuki, Mio Yagi and Katsushi Suzuki \\ Department of Veterinary Physiology, Nippon Veterinary and Life Science University, 1-7-1 Kyonano-cho, \\ Musashino-shi, Tokyo 180-8602, Japan \\ Correspondence should be addressed to H Suzuki Email: hiroetsu@nvlu.ac.jp
}

\begin{abstract}
Male rats with hypogonadism (hgn/hgn) experience sterility from testicular dysplasia, which is controlled by a single recessive gene, hgn. The postnatal growth of the seminiferous tubules was severely affected. In this study, we localized the hgn locus to a $320 \mathrm{~kb}$ region on rat chromosome 10 and detected the insertion of a $25 \mathrm{bp}$ duplication into the sixth exon of the sperm-associated antigen 5 (Spag5/astrin/MAP126) gene, which codes for a microtubule-associated protein. This mutation results in a truncated Spag5 protein lacking the primary spindle-targeting domain at the $\mathrm{C}$ terminus. Immunological staining with antibodies to markers for Sertoli and germ cells during the early postnatal period indicated that the abnormal mitosis with dispersed chromosomes in hgn/hgn testes occurs in proliferating Sertoli cells. Therefore, apoptotic Sertoli cell death would result from the disorganization of the spindle apparatus caused by defective Spag5. These findings suggested that the Spag5 is essential for testis development in rats and that the hgn/hgn rat is a unique animal model for studying the function of Spag5.

Reproduction (2006) 132 79-93
\end{abstract}

\section{Introduction}

Spermatogenesis is a central event in male reproduction. During this process, spermatogonia differentiate into functional spermatozoa, which carry the male genetic information into oocytes. The Sertoli cell is a highly specialized cell type responsible for spermatogenesis. The cytoplasm of Sertoli cells is extended into the lumen of seminiferous tubules in order to nurse germ cells at various stages of development. Since each Sertoli cell can support a limited number of germ cells, making the establishment of the normal complement of Sertoli cells during testicular development is important for ensuring a normal level of sperm production during adulthood (Sharpe et al. 2003). During the period from the late embryonic to the early postnatal stage, Sertoli cells proliferate rapidly and form a palisade-like distribution along the basement membrane of seminiferous tubules (Clermont \& Perey 1957). Once Sertoli cells become mature, they lose their proliferative activity (Sharpe et al. 2003). Despite the importance of Sertoli cells in the establishment and maintenance of testicular function, the mechanism regulating the differentiation of Sertoli cells is not fully understood. Especially, the molecular events surrounding the proliferation and differentiation of Sertoli cells during the perinatal period are not exactly known.

Male hypogonadic (hgn/hgn) rats are characterized by male sterility resulting from testicular dysplasia (Hakamata et al. 1988, Suzuki et al. 1988, 1993, 1998, 2004b), a short female reproductive life resulting from ovarian hypoplasia (Suzuki et al. 1992), progressive renal insufficiency resulting from renal hypoplasia (Suzuki \& Suzuki 1995, 1998, Suzuki et al. 1991, 2005, 2006), and body growth retardation (Suzuki et al. 1992). All of these effects are controlled by a single recessive allele (hgn) located on chromosome 10 (Suzuki et al. 1999, 2004a). In adult male $\mathrm{hgn} / \mathrm{hgn}$ rats, the plasma testosterone level is low, the gonadotropin levels are high, and testis weight is about $1 \%$ the weight of a normal testis (Hakamata et al. 1988). Histologically, some undifferentiated seminiferous cords remain in fibrous interstitial tissue and no spermatogenesis occurs in adult hgn/hgn testes (Suzuki et al. 1988). Moreover, the growth of seminiferous tubules is inhibited during the early postnatal period and Sertoli cells fail to make a line along the basement membrane because of their severely reduced number (Suzuki et al. 1998, 2004b). In the peritubular tissue of $h g n / h g n$ testis, a single layer of immature myoid cells is found around the 
tubules, mesenchymal cells form multiple layers, and the accumulation of extracellular matrix into basement membrane is defective (Suzuki et al. 1998, 2004b). Since in hgn/hgn testes, Sertoli cells often undergo apoptosis during their proliferative period and lose the expression of follicle-stimulating hormone receptor mRNA after postnatal day (PD) 12 (Suzuki et al. 2004b), their failure to proliferate and differentiate during the perinatal period may be the primary defect in male hypogonadism (Yagi et al. 2006).

To determine the candidate hgn gene, we constructed a fine linkage map around the hgn locus. Using RNA samples from neonatal testes, we performed RT-PCR experiments to identify candidate hgn genes. We found that a 25 bp duplication was present in the sixth exon of the gene encoding sperm-associated antigen 5 (Spag5/astrin/MAP126) of the hgn/hgn genome. The complete cDNA sequence of rat Spag5 determined by RACE-PCR method indicates that $h g n$ allele produce a truncated product lacking almost all the coiled-coil domain. Spag5 is a microtubule-associated protein expected as rat orthologue for human astrin/MAP126 (Fitzgerald et al. 2006), which is essential for cell mitosis progression (Gruber et al. 2002). Histologically, we observed apoptotic cell death and abnormal mitotic metaphases in the Sertoli cells of hgn/hgn testes during postnatal testicular development. These results suggest that the defect of functional Spag5 causes male hypogonadism and that Spag5 is essential for normal testis development in rats.

\section{Materials and Methods}

\section{Linkage analysis}

To construct a fine linkage map around hgn locus, we genotyped the backcross progeny with a newly generated polymorphic markers (Table 1) using previously obtained genomic DNA (Suzuki et al. 1999, 2004a). PCRs, separation of PCR products, and gel staining, and data analysis were done as previously described (Suzuki et al. 2004a).

\section{RT-PCR analysis of candidate genes}

The $h g n / h g n$ females were selected from the hgn-inbred strain derived from hypogonadism strain (HGN) by the laparotomy for the detection of renal hypoplasia at weaning (Suzuki et al. 1991). The +/hgn and hgn/hgn neonates were obtained by mating between the hgn/hgn females and the $+/$ hgn males. The $+/+$ neonates were derived from hgn-free dominant homo inbred strain derived from the HGN strain $(\mathrm{HDH})$. Total RNA was extracted from neonatal testes. Each $40 \mu \mathrm{l}$ RT reaction mixture containing $1 \mu \mathrm{g}$ total RNA, $0.25 \mu \mathrm{M}$ oligo (dT) primer, $1 \mathrm{mM}$ of each dNTP, and $10 \cup$ RNAse inhibitor was incubated at $65{ }^{\circ} \mathrm{C}$ for $5 \mathrm{~min}$ and cooled on ice.
After adding $5 \cup$ ReveTra Ace (Toyobo, Osaka, Japan), the samples were reverse transcribed by incubation at $42{ }^{\circ} \mathrm{C}$ for $1 \mathrm{~h}$ and heated at $95{ }^{\circ} \mathrm{C}$ for $5 \mathrm{~min}$ to inactivate the reverse transcriptase. Each PCR was performed in $20 \mu \mathrm{l}$ of a reaction mixture containing $1 \mu \mathrm{l}$ cDNA, $1 \mathrm{mM} \mathrm{MgSO}{ }_{4}, 0.3 \mu \mathrm{M}$ of each primer (Table 1), $0.2 \mathrm{mM}$ of each dNTP, $1 \cup$ KOD-Plus-DNA polymerase (Toyobo), and the reaction buffer supplied by the manufacturer. The amplification protocol consisted of 35 cycles of denaturation for $15 \mathrm{~s}$ at $94^{\circ} \mathrm{C}$, annealing for $30 \mathrm{~s}$ at $55^{\circ} \mathrm{C}$, and extension for $60 \mathrm{~s}$ at $68^{\circ} \mathrm{C}$, performed in a Thermal Cycler PTC-200 (MJ Research, Waltham, MA, USA). Gel electrophoresis, staining, and imaging were performed as described previously (Suzuki et al. 2004a,b).

\section{RACE-PCR of Spag5}

To determine the predicted amino acid sequence of rat Spag5, we performed 5'- and 3'-RACE using Cap Fishing Full-length cDNA Premix Kit (Seegene, Inc., Seoul, Korea). After heating the RNA samples at $75^{\circ} \mathrm{C}$ for 3 min, $5^{\prime}$ - or $3^{\prime}$-enriched cDNAs were synthesized in $20 \mu \mathrm{l}$ mixture containing $3 \mu \mathrm{g}$ total RNA, $10 \cup$ Super Script II RNase $\mathrm{H}^{-}$RTase (Invitrogen) and $0.5 \mu \mathrm{M}$ random hexamers (for $5^{\prime}$-RACE) or $0.5 \mu \mathrm{M}$ oligo (dT) primer (for $3^{\prime}$-RACE) by incubation at $42{ }^{\circ} \mathrm{C}$ for $1 \mathrm{~h}$. Following addition of $3 \mu$ l CapFishing adaptor and $60 \cup$ RTase, the mixture was further incubated at $42{ }^{\circ} \mathrm{C}$ for $30 \mathrm{~min}$. The samples were heated at $95^{\circ} \mathrm{C}$ for 5 min to inactivate the RTase, and diluted to $200 \mu \mathrm{l}$ with water. Each $5^{\prime}$-RACEPCR was performed in $25 \mu \mathrm{l}$ of a reaction mixture containing $2.5 \mu \mathrm{l}$ diluted first-stranded cDNA, $12.5 \mu \mathrm{l}$ SeeAmp Taq Plus Master Mix, $0.2 \mu \mathrm{M}$ 5'-RACE primer, and $0.2 \mu \mathrm{M}$ 3'-target primer. 3'-RACE-PCR was performed in similar reaction mixture containing $0.2 \mu \mathrm{M}$ 3'-RACE primer and $0.2 \mu \mathrm{M} 5^{\prime}$-target primer (Table 1). The amplification protocol consisted of 35 cycles of denaturation for $40 \mathrm{~s}$ at $94{ }^{\circ} \mathrm{C}$, annealing for $40 \mathrm{~s}$ at $58{ }^{\circ} \mathrm{C}$, and extension for $60 \mathrm{~s}$ at $72{ }^{\circ} \mathrm{C}$. The PCR products were electrophoresed on agarose gels as described above.

\section{PCR detection of Spag5 mutation in genomic DNA}

Genomic DNA was isolated from the livers of the rats derived from the HDH, HGN (Suzuki et al. 1988), and HGNII (hgn-inbred strain derived from Wistar-Imamichi closed colony) (Suzuki et al. 2005) strains. All had been genotyped by test mating. Rats were assumed to be $+/+$ if, after mating with carriers, none of at least 11 pups was affected. PCR of genomic DNA and polyacrylamide gel electrophoresis were performed as described (Suzuki et al. 2004a). The sequence of the Spag5 cDNA fragment containing the mutation site of the hgn allele was BLAST-searched against the rat genome (Map Viewer, 
Table 1 The primer sequence of polymorphic markers, RT-PCR for candidate genes, and genotyping of mutation

\begin{tabular}{|c|c|c|c|c|}
\hline Name & AC number & Position & Forward & Reverse \\
\hline \multicolumn{5}{|c|}{ Polymorphic markers } \\
\hline M1 & AC095686 & $255143-255323$ & TGGCAAGACGACAGGTTGAA & AGTGTGCCACTCTCGGGACT \\
\hline M2 (Supt6 h) & AC095686 & $172146-172446$ & GTGTGAGGCTTCCAGATGCC & GCTTCAGAATAAAACATTTCCСТCAT \\
\hline M3 (Sdf2) & AC095686 & 149974-150194 & GGTCCCTGCTTAAGGAGGACA & GGTGTGTGGTGGGTGTTCC \\
\hline M4 (Slc $13 \mathrm{a} 2)$ & AC097687 & 27624-27913 & TCTACCATACTTAAATGAAGAGAGACTCTG & GCTCAGGCAATTAACATCTGTCTGT \\
\hline \multirow{2}{*}{\multicolumn{5}{|c|}{ 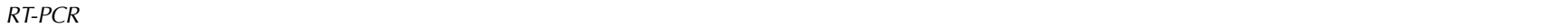 }} \\
\hline & & & & \\
\hline SDF2 & XM213377 & 510-1113 & CTGCACAGCСАCСАТTTCACT & ATGCCAAGCTCCTGTGGAGTT \\
\hline LOC303280 & XM220636 & $4977-5764$ & TGGACTTGCCTGTTAGATGGC & ACTGCAGCGCCAATAAAATG \\
\hline PIGS & BC083862 & $587-1258$ & CTTTGACAGAGGATGTGCTTGCT & GTCCTTCACTCTTCGGTCCTGA \\
\hline SPAG5-1 & XM340848 & 78-926 & GAGCCTCTGGTGTGGTATGG & CTGGGCCAGGTATCTTGTGT \\
\hline SPAG5-2 & XM340848 & $697-1625$ & TTGACCATGTTGGTCAAGTGT & CGGGACATCCAAGTCTCTGA \\
\hline SPAG5-3 & XM340848 & $1441-2293$ & AGTTTTCTCGСАСТСССТGA & CTTTAAGGGCCATTTCCTCC \\
\hline SPAG5-4 & XM340848 & $2183-3177$ & AGACCCTGGTTTCCTCСTGT & AGAATGCTGGTGCGTCTTCT \\
\hline SPAG5-5 & XM340848 & $2146-2440$ & CATGTGCAAGATGACAGAGTGA & CTGTGTGAAGCCCTATCAGTTG \\
\hline G3PHD & & & ACCACAGTCCATGCCATCAC & TCСАССАСССТGTTGCTGTA \\
\hline \multicolumn{5}{|l|}{$5^{\prime}-R A C E$} \\
\hline $3^{\prime}$-TARGET & XM340848 & -1558 & & ССТCCTGGGGTCCСАTTTCTACTAGAC \\
\hline \multicolumn{5}{|r|}{$x_{1}$} \\
\hline $5^{\prime}$-TARGET & XM340848 & $2970-$ & CATGGAGTTTGTAGATGAAGAGAGTCAAG & \\
\hline SEQ-1 & XM340848 & $2988-$ & AGAGAGTCAAGTTGCTCACCTG & \\
\hline SEQ-2 & XM340848 & 3569 & AAATCTGTGAACTGCACACAAGAC & \\
\hline \multicolumn{5}{|c|}{ 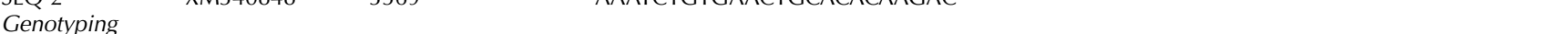 } \\
\hline SPAG5-G & NW0433 & 5321196-5321606 & СCTGCACAGATGTGATACCCT & ССТСАССТGТСССТGАСАСАТ \\
\hline
\end{tabular}

National Center for Biotechnology Information (NCBI) http://www.ncbi.nlm.nih.gov/mapview/). Primer sequences were subsequently designed to flank the mutation site of genomic DNA (SPAG5-G, Table 1).

\section{Sequencing}

Following gel electrophoresis of the first PCR products, a portion of each band was picked from the gel with a pipette tip and used for a second round of PCR. The resulting products were purified using QIAquick PCR purification Kit (Qiagen $\mathrm{GmbH}$ ) and directly sequenced in both the sense and antisense directions by an outside supplier (Hitachi Instrument Service Co., Ltd). 5'-RACEPCR samples were subsequently cloned into pGEM T-Easy Vector (Promega) and sequenced. 3'-RACE-PCR samples were directly sequenced using SEQ-1 and SEQ2 primers (Table 1 ). The sequence data were integrated and analyzed using Genetyx-Mac Ver. 12 (Genetyx Co., Shibuya-ku, Tokyo, Japan).

\section{Preparation of paraffin sections and periodic acid Schiff (PAS) staining}

Male hgn/hgn rats and their phenotypically normal littermates $(+/$ hgn and $+/+)$ from the HGN strain were sacrificed on PD 0 and 1 by an overdose of ether, and their testes were fixed in Bouin's solution for $2 \mathrm{~h}$. Paraffin sections were prepared as described (Suzuki et al. 2004b, Yagi et al. 2006) and serial sections were deparaffinized in xylene, hydrated in graded alcohol, and immersed in $0.01 \mathrm{M}$ PBS ( $\mathrm{pH}$ 7.4). To examine mitotic cells in neonatal testes, tissue sections were stained with PAS stain and hematoxylin (Suzuki \& Suzuki, 1995).

\section{Immunohistochemistry and TUNEL staining}

Tissue sections were processed in a microwave $(3 \min \times 5)$ in $0.01 \mathrm{M}$ citric acid buffer $(\mathrm{pH} 6.0)$ to reactivate their antigenicity, soaked in water, immersed in $2 \mathrm{M} \mathrm{HCl}$ for $20 \mathrm{~min}$, and soaked in PBS. The sections were immersed in methanol containing $3 \%$ periodic acid to inactivate internal peroxidases and incubated in PBS containing $5 \%$ skim milk or $10 \%$ normal rabbit serum for 60 min to block non-specific antigen-antibody reactions. Sections were incubated overnight at $4{ }^{\circ} \mathrm{C}$ with antibodies against GATA-binding protein 4 (GATA-4; goat polyclonal, 1/500 dilution; Santa Cruz Biotechnology, Santa Cruz, CA, USA), Mullerian-inhibiting substance (MIS, goat polyclonal, 1/500 dilution; Santa Cruz Biotechnology), mouse VASA homolog (rabbit polyclonal, 1/1000 dilution; the kind gift of Dr T Noce) (Toyooka et al. 2000), and vimentin (VM, monoclonal, 1/3 dilution; clone V9, BMB, Mannheim, Germany). The sections were rinsed in PBS and incubated with Histofine Simple Stain Rat PO (MULTI) (Nichirei Co., Tokyo, Japan) for monoclonal primary antibodies, Hitofine SAB-PO (G) kit (Nichirei Co.) for goat polyclonal primary antibodies, and Histofine Simple Stain Rat MAX-PO (R) (Nichirei Co.) for rabbit polyclonal primary antibodies. Apoptotic cells were detected with an in situ apoptosis detection kit (TaKaRa Bio, Inc., Shiga, Japan). The slides were incubated with 3,3'-diaminobenzidine tetrahydrochloride and counterstained with hematoxylin, and digital images were obtained as described (Suzuki et al. 2004b, Yagi et al. 2006). 


\section{Cell proliferation assay}

Pups were intraperitoneally injected with 5-bromo-2' deoxyuridine (BrdU $100 \mathrm{mg} / \mathrm{kg}$ ) on PD 1. Two hours later, the rats were sacrificed and their testes were removed and fixed overnight at $4{ }^{\circ} \mathrm{C}$ in $4 \%$ buffered formalin. Paraffin sections were prepared as described above, and BrdU incorporated into S-phase cells was detected by immunohistochemistry as described (Sugihara et al. 1986). The sections were subsequently processed for anti-MIS immunostaining to detect BrdUpositive Sertoli cells. Briefly, after deparaffinization in xylene, the sections were incubated in $4 \mathrm{M} \mathrm{HCl}$ for $30 \mathrm{~min}$ and in $0.01 \%$ trypsin in PBS for $10 \mathrm{~min}$ and soaked in PBS. After the incubation in PBS containing $10 \%$ normal rabbit serum for $10 \mathrm{~min}$ to block nonspecific antigen-antibody reactions, the sections were incubated with primary antibody (anti-BrdU MAB, clone BRD.3, Lab. Vision Corp., Fremont, CA, USA) for $30 \mathrm{~min}$. Following immersion in PBS, primary antibodies were detected with streptavidin and biotin complex methods (Histofine SAB-AP kit; Nichirei Co.). A Fast Blue substrate kit (Nichirei Co.) was used to detect the activity of alkaline phosphatase conjugated with streptavidin. After stopping the reaction by immersion in tap water, the sections were incubated in $0.1 \mathrm{M}$ EDTA for $40 \mathrm{~min}$ at $95^{\circ} \mathrm{C}$, cooled for $1 \mathrm{~h}$ at $\mathrm{RT}$, and rinsed in tap water. Following immersion in PBS, MIS immunostaining was done as described above.

\section{Animals \\ All rats were fed a certified commercial diet (CR-LPF; Oriental Yeast Co., Ltd, Tokyo, Japan) and maintained in a clean conventional animal facility (Suzuki et al. $2004 a, b)$. All experimental procedures and care of animals were in accordance with the guidelines of the Animal Care and Use Committee of Nippon Veterinary and Animal Science University.}

\section{Results}

\section{Fine linkage mapping}

We previously reported that the hgn locus was linked to aldorase $\mathrm{C}$ (Aldoc) and located in an $840 \mathrm{~kb}$ region between D10Rat195 and D10Rat68 (Suzuki et al. 2004a). This region includes an unsettled segment of rat chromosome 10, in which the order of loci is opposite to that reported in the homologous regions of mouse chromosome 11 and human chromosome 17 . Thus, the positions of some of the markers mapped on our linkage map were inconsistent with those presumed from the rat physical map obtained from the NCBI (Map Viewer, NCBI, World Wide Web). Using BLAST, we searched BAC clones for the marker sequences on our fine linkage map against Baylor Rat Data (Rat Genome Project, Human Genome Sequence Center at Baylor College of
Medicine, http://www.hgsc.bcm.tmc.edu/projects/rat/). To narrow the region that includes the hgn locus, we identified fragments containing short tandem repeats in the sequences of the BAC clones AC095686 and AC097867, which covers most of the region containing the hgn locus. Using PCR primers designed to amplify these fragments, we identified five PCR fragments (M1-M5) (Table 1) that showed polymorphisms between HGN and Brown Norway (BN) strain. We, therefore, genotyped the backcross progeny with these markers using previously obtained genomic DNA (Suzuki et al. 1999, 2004a). The fine linkage map revealed that the $h g n$ locus was linked to $M 3$ (located in an intron of stromal cell-derived factor 2 (Sdf2)), Arb9 (Aldoc), D10Rat69, and whn (Foxn1), and was located between M2 (Supt6 $h$ ) and M4 (S/C13a2) (Fig. 1A). The order of these loci (i.e. Supth6-sdf2-Aldoc-Foxn1-S/C13a) in our fine linkage map was consistent with the order reported for the homologous regions of mouse chromosome 11 and human chromosome 17 (Suzuki et al. 2004a) indicating that, in the rat, the hgn locus was located between Supth6 $h$ and Slc3a.

\section{Positional candidate analysis}

Seven genes with known or predicted function were mapped to this region (Fig. 1A). Aldoc is expressed in brain-specific manner (Kukita et al. 1988). Unc119 (UNC-homology, HRG4) is exclusively expressed in photoreceptors, and a mutation of Unc119 is related with retinal degeneration (Kobayashi et al. 2000). Nude rats with a mutation of Foxn1 (Forkhead box N1) have a phenotype obviously different from that of $h g n / h g n$ rats (Segre et al. 1995). These genes, therefore, could be excluded as a candidate gene. Phosphatidylinositol glycan, class S (Pigs) is involved in glycosyl phosphatidylinisotol (GPI)-anchor biosynthesis in cell membrane (Ohishi et al. 2001). Sdf2 shows ubiquitous expression pattern in adult mouse organs (Hamada et al. 1996) and its physiological function have not been determined. There has been no information about the physiological function of hypothetical protein, LOC303280 gene (Map Viewer). Although the expression of Spag5 (astrin) is detected in many human tissues and cell lines (Chang et al. 2001, Mack \& Compton 2001), Spag5 is abundantly expressed in testes (Shao et al. 2001), and the alternatively spliced variant of Spag5 is highly expressed in human kidney (Chang et al. 2001). Therefore, Spag5 is the most possible candidate gene as hgn mutation. Pathological studies performed in hgn/ hgn rats have indicated that the gene responsible for $h g n$ is expressed in perinatal testes themselves (Suzuki et al. 1993, 1998, 2004b). We, therefore, assayed the expression of the candidate genes in the neonatal testes of normal $(+/+$ and $+/$ hgn) and $h g n / h g n$ rats. Although LOC303280, Spag5, Sdf2, and Pigs were expressed in neonatal rat testes, the levels of expression of $L O C 303280$, 

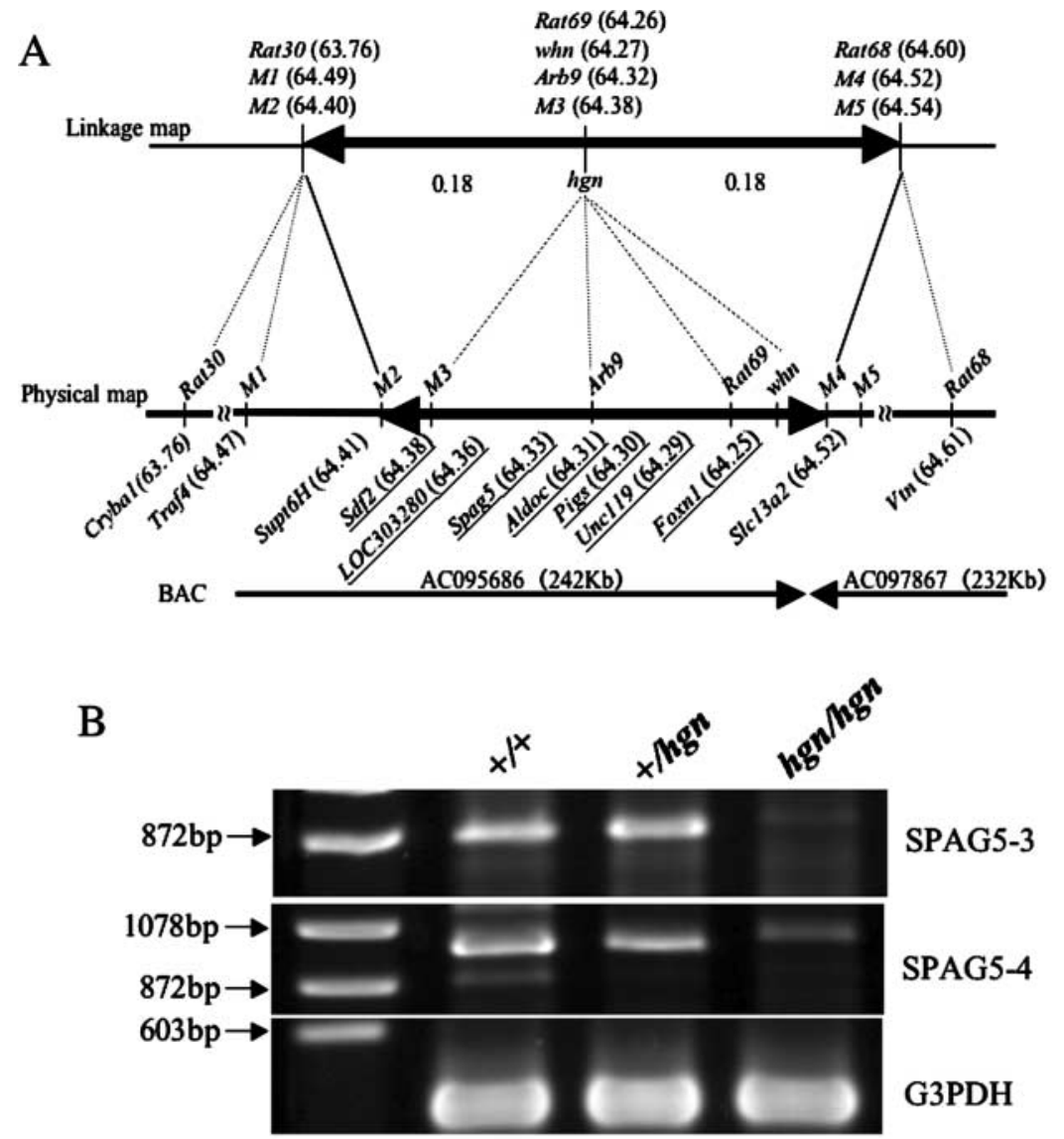

SPAG5-3

SPAG5-4

G3PDH

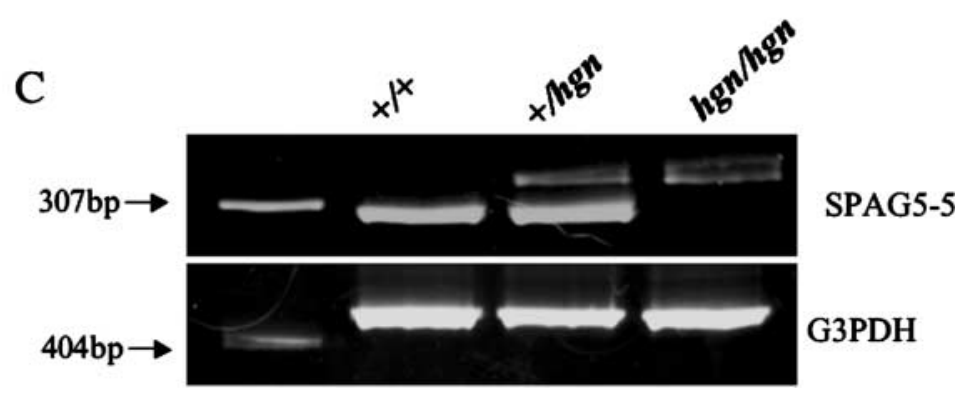

Figure 1 (A) Fine linkage map showing the location of newly generated markers (M1-M5) in relation to other loci around the hgn locus. The hgn locus is located in the region between M2 and M4. The physical map shows the position of new markers close to the hgn locus relative to genes with known or inferred functions. The functional genes located within the region between M2 (Supt6 $h$ ) and M4 (Slc13a2) are underlined, and their relative position, in kilobase, is shown in parentheses. BAC clones covering this region are also shown. (B) Expression of Spag 5 mRNA in neonatal $+/+(\mathrm{HDH}),+/$ hgn, and hgn/hgn testes. Each RNA sample was reverse transcribed and amplified using the primers for SPAG5-3 and -4 shown in the Materials and methods section. As internal controls, a G3PDH fragment was amplified from the same RNA samples. The PCR products were electrophoresed on agarose gels. (C) Small segments of Spag5 cDNA, which contain the region overlapped in SPAG-3 and SPAG5-4, were amplified using SPAG5-5 primers, and electrophoresed on acrylamide gels. In addition to intense band observed in $+/+$ and $+/$ hgn testes, the weak band with large molecular size was observed in + /hgn and hgn/hgn testes.
Sdf2, and Pigs were comparable in hgn/hgn and normal testes (data not shown). However, the level of Spag5 mRNA expression was extremely lower in hgn/hgn neonatal testes than in normal $(+/$ hgn and $+/+)$ neonatal testes. Similar results were obtained when PCR were performed using SPAG5-3 and SPAG5-4 primers (Fig. 1B). Since the molecular sizes of the products of SPAG5-3 and SPAG5-4 appeared to be slightly larger in hgn/hgn testes than in normal testes, we amplified a small segment (SPAG5-5) containing the region overlapped in SPAG5-3 and SPAG5-4, and we separated the PCR product by nondenatured polyaclyamide gel electrophoresis. In addition to the intense band of which molecular size was identical with that of a single product in $+/+$ testis, another weak band with large molecular size was detected in $+/ h g n$ testes. In hgn/hgn testis, only a single weak band with large molecular size was detected (Fig. 1C).

\section{Determination of Spag5 cDNA sequence}

To confirm the Spag5 mutation in hgn/hgn rats, we directly sequenced the PCR products of SPAG5-3 and SPAG5-4 in hgn/hgn and $+/+$ rats. The full-length sequence of rat Spag5 cDNA has not been reported, and we could not detect any specific amplification in RT-PCR using the upstream primers, SPAG5-1 and -2. To predict the amino 
acid sequence of the Spag5 protein, we determined the 5'- and 3'-sequence of the Spag5 cDNA using RACE-PCR method. The rat Spag5 cDNA sequence (AB231661) determined by our sequence analysis was almost corresponding to the sequence after nt 980 of the automated computationally predicted cDNA sequence of rat Spag5 (XM340848), although the sequence of nt 500-820 of AB231661 was not found in the sequence of XM340848. The partial cDNA sequence (AF111111) of rat Spag5 (Shao et al. 2001) was corresponding to the sequence of nt 2429-3862 of AB231661. The $3561 \mathrm{bp}$ ORF of AB231661 encodes a protein of 1187 amino acids (132 kDa). The amino acid sequence of rat Spag5 protein was 63 and 85\% homologous to human and mouse Spag5 respectively. We found that the initial 60aa and the latter 500aa were highly conserved among these species (Fig. 2). The former is a sequence unique to Spag5, and the latter contains two large coiled-coil domains.

\section{Identification of a mutation in cDNA and genomic Spag5 sequences}

When we compared the Spag5 cDNA sequences of hgn/hgn and $+/+$ testes, we found that the former contained a $25 \mathrm{bp}$ fragment, a duplication of an adjacent sequence, inserted at position nt 1742 . This insertion results in the addition of 15 amino acids after amino acid 562 of the wild-type protein, and the frame shift leads to the introduction of a stop codon, producing a truncated product lacking almost all of the coiled-coil domain (Fig. 3). This mutation was confirmed by amplifying the fragment surrounding the insertion in genomic DNA derived from $h g n / h g n,+/ h g n$, and +/+ rats (Fig. 4). The genotype of the Spag5 allele was completely consistent with the hgn genotype in the HGN and HGNII strain (Fig. 4A). Since the Spag5 mutation was not found in the rats of other strains (OCD (Suzuki et al. 2000) and HN (Suzuki et al. 1987)), derived from an original closed
A 1 MHRVKTLNLGLSPSPQSGKPAMRTPLRELKLQPEALADSGKGP-MFSSLTPYLRRLDLKERRNSSSPVNF VNAENSSPVDFVNTENT SPV B 1 MMIRVKTLNL GL SPSPQKGKPAMSTPLRELKL QPEALADSGKGPSMI SALT PYL CRLEL KERCN C 1 MHRVKKLSLSLSPSPQTGKPSMRTPLRELTLQPGAL TNSGKRSPACSSLTPSLCKLGLQEGSN-

90 DFONTENNFLSEQF SHPSEYIEACQRESDLTPESSSP-FNTLEKAVEAMDOFVAEPIDDGIVKTMVLLPFSL GQQQDLMLQAHLDTAER 72 - - NTENNF LSEQF SHPSTHIEACQRESDPTPE SNSL-FHTLEEA IET VDDFVVDPRDDS IVE SMVLLPF SL GQQQDLML QAHLDTT AER 73 ---NKRTDLSSEHF SHSSKYLLETCQHESDEQPL DP IPQISSTPKT SEE -- --AVDPLGNYMVKTIVLVPSPL GQQQDMIFEARLD TMAET

179 NKSSLKESLGLEDLVEKEAAPCVEDSL PETVAIR - . . .

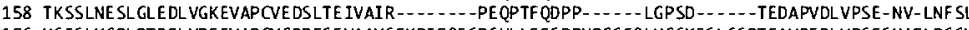
156 NSISLNGPLRTDDL VRE EVAPOMGORFS VVAVSEKPIFOESPSHLLEESPPNPCSEQLHCSKESL SSRTEAVREDLVPSESNAFLPSSV

247 ACLSPSTVLTKDF SVDHVDPGE ETAENRVIQE VEKSFLALPEEAGL GDQALAVNAEDVSSLYLSSSLVEMGPQEAPGPTAEDASRIPDLE 226 ARLSPSAVLAQDFS VDDVDPGEETVENRVLOEME TSFPTFPEEAEL CDQAPAANAEAVSPLYLTSSLVEMGPREAPGPTVEDASR IPGL 246 LWLSPSTALAADFR WHVDPEEE IVEHGAME EREMRFPTHPKESET EDQALVSSVEDILSTCLTPNLVEMESQEAPGPAVEDVGRILGSD 337 SE TWMSPLAWLEKGWTSVMLQSLRQSLPFSKS VLQDAAVGNTPHS TYSVG TSFTPPVPLE …........ VGTKDSTSE TERLLLGCRP 316 SE TWMSPLAYLLEKGWTSVMLONLRQSLSFS-SVLQDAAVGNTPLATCSVGTSFTPPAPLE -........-VGTKDSTSE TERLLLGCRP 336 TE SHMSPLAWLEGWWTSVML ENLRQSL SLP-SMLRDAAIGTPFSTCSVGTWFTPSAPQEKSTNT SQTGLVGTKHSTSETEQLLCG - RP 17 PDLAAL SRHDLEENLLNAL VLLEVLSHQLQAWKSQL TVPSROAQDSSTQTDSSAAVVTKTPKHLQDSKEIRQALLQARNITHSHGLVSRD 395 PDLATL SRHDLE ENLLNSL VLLEVLSHQLQAWKSQL TVPHREARDSSTQTOSSPCGVTKTPKHLQDSKEI RQALLQARMMQSYGGLVSGD 424 PDLTAL SRHDLEDNLLSSLVILEVLSRQLRDWK SQLAVPHPETQDSSTQTDTSHSGITNKLQHLKE SHEMGQALQQARMMUSWVLISKE

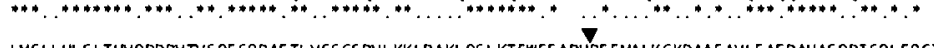
507 LMSLLHL SLTHNQDDRVTVSQE SQRAE TLVSSCSRVLKKLRAKLQSLKTEWEEARHREEMALKGKDAAEAVLEAFRAHASQRI SQLEQG 485 LLSLLHLSL THVQE GRVTVSQESQRSKT LVSSCSRVLKKLKAKLQSLKTECEEARHSKEMALKGKAAAEAVL EAFRAHASORI SQLEQG 514 LISLLHL SLLHLEEDKT TVSQE SRRAE TLVCCCFDLLKKLRAKLQSLKAEREEARHRE EMALRGKDAAE IVLEAFCAHASQRISQLEQDL

597 TSVQE FRGLLQEAQTQL IGLHT EQEELAQHTVSLTSALQQDWTSVQQNYGTKAALLSRSRELTKKL TAKSRQALQERDAAIEEKDQWKE 575 TSMQEFRGLLQEAQTQL IGLHTEQKE LAQQTVSLSSALQQDWT SVQLNYG I HAALL SWSRELTKKL TAKSRQALERDAAIEE KKQVVKE

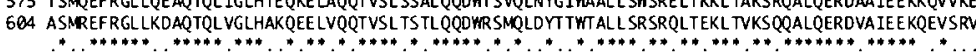

687 VEQVSAHLEDCKGQIEQLKLENSRLTADLSAQLQTLASTENELKELQSQHSHCVQDLAMKDELLCQLTQS NKEQAAQWOKEE TEL KHRQA 665 VEQVSAHLEDCKGQIEQLKLENSRLTADLSAQLQILTSTESQLKEVRSQHSRCVQDLAVKDELLCQLTQSNKEQATQWOKEEMELKHIQA

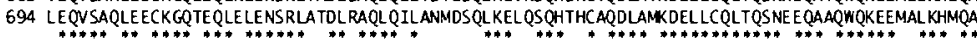

777 ELLQQKAVLAKEVQDLRETMEFVDEESQVAHLEL GQIESQLKATLEVLRERSL QCE TLKDTVE SLRAELASTEAKHEOOAL EKTHQHSKE 755 ELLQQQAVLAKEVQDLRETVE FIDEE SQVAHRELGIESQL KVTLELLRERSLQCETLRDTVDSLRAELASTEAKHEKQALEKTHQHSQE 784 ELQQQQAVLAKEVRDL KETLE FADQENQVAHLELGQVECQLKTTLEVLRERSLQCENLKDTVENLT TKLASTIADNQEQDLEKTRQY SQK

867 LCLLAEQLQSL TLF LEAKLEENKAESDI ILPSTGCAPAQEHPPSSDSSVSEQTPTAWDEVPEPAPVPLL GSVKSAFTRVASTAPFRPTE 845 LRLLAEQLQSLTLF LQAKLKENKAESEIILPSTGSAPAQEHPLSNDSSISEQTPTAAVDEVPEPAPVPLLGSVKSAF TRVASMASFQPTE 874 LGLLTEQLQSLTLFLQTKL KE -KTEQETLLLSTACPPTQEHPLPNDRTFLGSILTAVADEEPESTPVPLL GSDKSAFTRVASMVSLQPAE

957 TPALEKSLAEMSAVLQELQRLCALLQESKEEAVGVL ORE ICELHTRLQAQEEE HQEAQKAKEADIEKL NQAL CLRHKNEKELLEVIQKON 1046 935 TPDLEKSLAEMS TVLQELKSLCSLLQES KEEATGVLOREICELHSRLQAQEEEHQEAL KAKEADME KLNQALCLLRKNEKELLEVIQKON 102 963 TPGMEE SLAEMS IMTEL LSLCSLLQESKEEAIRTLQRKICEL QARLQQQQEEQHQEV VQKAKEAOIEKLNQALCLRYKNEKEL QEV IQQQN

1047 EKILGQIDTSGQLINLREEVTQLTRL LRRAE TETKVLQEALEGQVOPSCQLMATNWIQEKVFL SQEVNKLRAMFLEVKNEKKQLMDKYLS 1136 1025 EKILGQIDKSGQLIMLREEVTQLTQS LRRAETE TKVLQEALEGQLOPSCQLMATNWIQEKVFL SQEVSKL RVMFLEMKTEKEQLMDKYLS 1114 1053 EKIL EQI DKSGELISLREEVTHLTRSLRRAE TE TKVLQEALAGQLOSNCQPMA TNWIQEKVWL SOEVOKL RVMFLEMKNEKEKLMIKFQS 1142 $* * * . . * * .$.

1137 HRHILEENLRRSDTELKKLDDTIQHIYETLLSIPEVVKSCKELQGLLEFLS 1115 HRHILEENLRRSDTELKKLDDTIQHNYETLLSIPETMKSCKELQGLLEFLS

1143 HRNILEENLRRSDKELEKLDDIVQHIYKTLLSIPEVVRGCKELQGLLEFLS
Figure 2 Comparison of the amino acid sequences of rat (A), mouse (B), and human (C) Spag5 proteins. The rat amino acid sequence was predicted from rat Spag 5 cDNA sequence determined by RACE-PCR method. Arrowhead indicates the position at 562aa. 


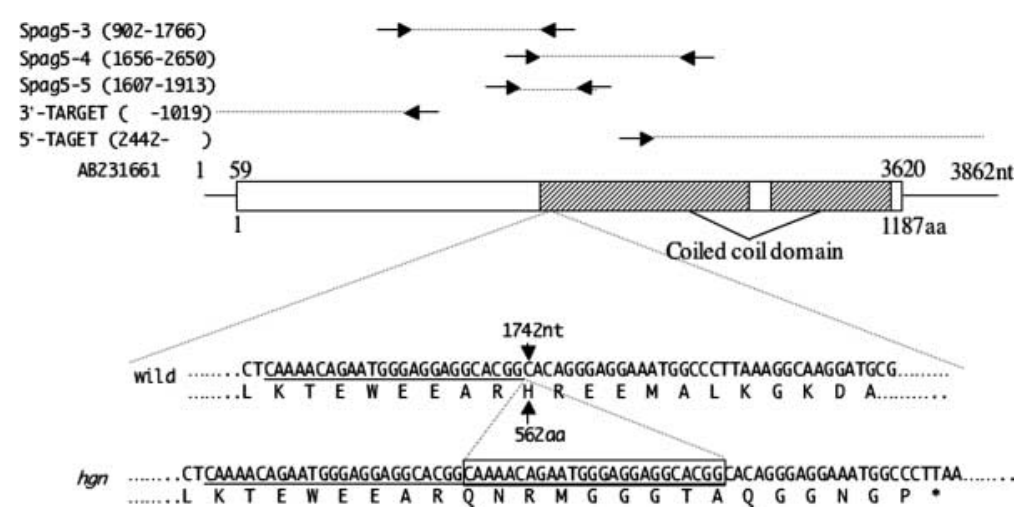

Figure 3 Diagram of rat Spag5 cDNA and transcript showing the position of hgn mutation. cDNA sequence and predicted amino acid sequence of the wild type and hgn alleles of Spag5 were shown. In the hgn allele, a 25 base duplication (Box) of a sequence present in the wild-type allele (underline) causes a frame shift mutation, leading to the insertion of a stop codon $\left(^{*}\right)$. The position of primers used in the RT-PCR and RACE experiments were also shown.

colony of Wistar-Imamichi rats, this mutation was unique for hgn/hgn rats of HGN and HGNII strains. Part (517-650 bp) of the Spag5 cDNA could not be found in the Spag5 sequence of rat genome database because of gaps in the draft sequence (Map Viewer, NCBI, World Wide Web). Comparing the exon-intron organization of rat Spag5 gene with those of mouse and human Spag5 genes indicate that the $25 \mathrm{bp}$ fragment is inserted into the sixth exon of the Spag5 gene (Fig. 4B).

\section{Abnormal mitosis and apoptosis in hgn/hgn testes}

Spag5 is a microtubule-associated protein, which is functionally related with the stability of the spindle apparatus in mitotic cells (Mack \& Compton 2001, Chang et al. 2001, 2003, Gruber et al. 2002, Fitzgerald et al. 2006). In order to obtain histological evidences involved in the defect of the Spag5 function in hgn/hgn rats, we characterized cell mitosis and apoptosis in the testes at PD 1. In the normal testes at PD 1, Sertoli cells form a line along the basement membrane of seminiferous tubules (Fig. 5A). These cells often undergo mitosis, with gonocytes located in the center of the tubules arresting during G0 (Fig. 5C). In the hgn/hgn testes, the number of Sertoli cells is very low, so they fail to make a line along the basement membrane (Fig. 5B). We often found abnormal mitotic metaphase cells, which contained large amount of cytoplasm and diffused chromosomes in the hgn/hgn tubules (Fig. 5D). Although no TUNELpositive cells were found in normal testis at PD 1 (Fig. 6A), we often observed TUNEL-positive apoptotic cells and abnormal mitotic metaphases in hgn/hgn tubules (Fig. 6B). In disagreement with the increased appearance of mitosis, the number of MIS-positive Sertoli cells containing BrdU-positive nuclei was apparently low in hgn/hgn testes (Fig. 6D and F) compared with that in normal testes (Fig. 6C and E).

\section{Identification of cell types undergoing mitosis and apoptosis}

To determine the cell types undergoing abnormal mitosis and apoptosis, we stained tissue sections with antibodies specific for marker proteins of germ cells (VASA; Toyooka et al. 2000), Sertoli cells (MIS; Kuroda et al. 1990), Sertoli and Leydig cells (GATA-4; Ketola et al. 1999), and testicular somatic cells (VM; Paranko et al. 1986). In normal testes at PD 1, the cytoplasm of gonocytes, the mitotic arrest phase of germ cells, were specifically stained with anti-mouse VASA antibody (Fig. 7A and B). Sertoli cells were positive for GATA-4, MIS, and VM. GATA-4 staining was observed in the nuclei and cytoplasm (Fig. 7C and D), and MIS staining in the cytoplasm (Fig. 8A and B). VM immunostaining in Sertoli cells was observed in their cytoplasm under the nucleus (Fig. 8C and D). These marker proteins were detected in mitotic and apoptotic cells. In hgn/hgn testes, these proteins showed similar patterns of cell specificity, consistent with the relatively reduced number of Sertoli cells (reduction of total GATA-4 and MIS staining) and the relatively increased number of gonocytes (increased total VASA staining) in seminiferous tubules. Abnormal mitotic and apoptotic cells were both negative for VASA (Fig. 7B), but positive for GATA-4 (Fig. 7D) and MIS (Fig. 8B). VM immunostaining was located in the cell membrane of abnormal mitotic cells in hgn/hgn testes (Fig. 8D). These findings indicate that, in hgn/hgn testes, the abnormal mitosis with dispersed chromosomal distribution and apoptosis occurred predominantly in Sertoli cells rather than gonocytes.

\section{Discussion}

Male hypogonadic mutant rats were first detected in the fifth generation of a hydoronephrotic strain derived from a closed colony of Wistar-Imamichi rats (Suzuki et al. 1988). 


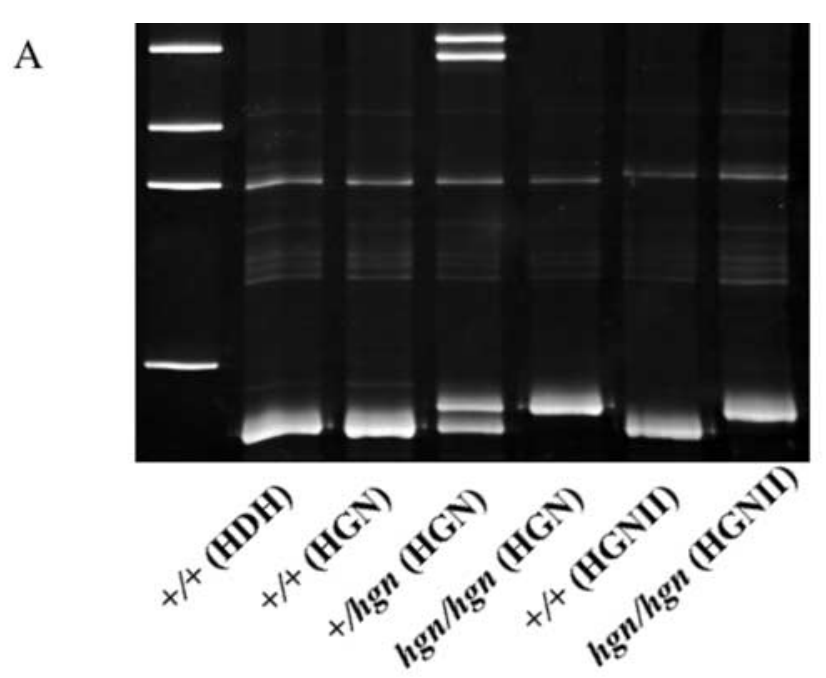

B

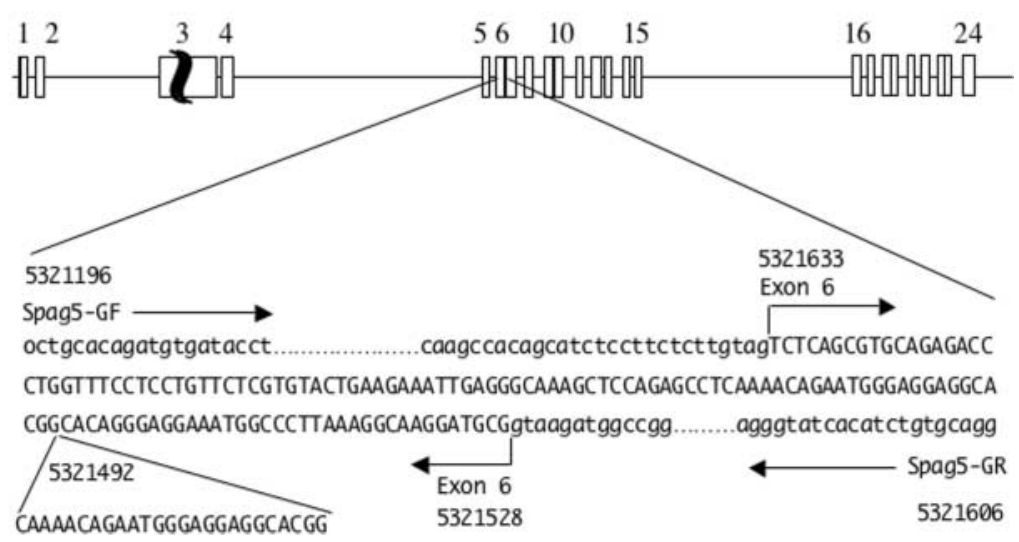

Figure 4 (A) PCR amplification of the Spag5 hgn and wild-type alleles in genomic DNA from rats with the indicated genotype. HDH, hgn-free dominant homo inbred strain derived from the HGN strain; HGN, hgn-inbred strain derived from hydronephrosis (HN) strain; HGNII, hgn-inbred strain derived from Wistar-Imamichi closed colony. (B) Genomic sequence showing that the hgn allele contains an insertion of a 25 base fragment into the sixth exon of Spag5 gene.

The HGN inbred strain has been maintained in our laboratory by sister-brother mating between carriers. We have described the pathophysiological characters of these $h g n / h g n$ rats, in which testicular dysplasia was used to study testes development (Hakamata et al. 1988, Suzuki et al. 1988, 1993, 1998, 2004b, Yagi et al. 2006). In addition, we have used the renal hypoplasia occurring in these rats as a model of oligomeganephronia and chronic renal failure (Suzuki \& Suzuki, 1995, 1998; Suzuki et al. 1991, 2005, 2006). Since no other knockout mouse or mutant rat showing a similar phenotype has been reported, we started linkage analysis in 1997 and located the responsible gene on rat chromosome 10 (Suzuki et al. 1999). Since hgn/hgn females can be distinguished from phenotypically normal females by the presence of renal hypoplasia (Suzuki et al. 1991, 1992), 126 hgn/hgn females were selected from the HGN inbred strain by the laparotomy for the detection of renal hypoplasia at weaning. Five hundred and sixty-five male backcross progeny were obtained by mating between $F_{1}$ males (obtained by mating $+/+$ Brown Norway male rats with hgn/hgn $\mathrm{HGN}$ female rats) and $h g n / h g n$ females, and these animals were genotyped by microsatellites around hgn locus. In our previously described fine linkage map, we restricted the region that included the hgn locus to an $840 \mathrm{~kb}$ region of rat chromosome 10 (Suzuki et al. 2004a). In this study, we used newly generated markers to narrow the region to $320 \mathrm{~kb}$, which includes seven genes with known or predicted function. Semi-quantitative RT-PCR analysis revealed that the level of expression of Spag 5 was much lower in $h g n / h g n$ than in normal $(+/+$ and $+/$ hgn) testes. In consistent with these findings, the level of Spag5 was extremely lower in $h g n / h g n$ kidneys than in normal kidneys (data not shown). We found that, in hgn/hgn testes, there was a 25 bp insertion in the sixth exon of Spag5 gene. The extremely low level of Spag5 expression in hgn/hgn 

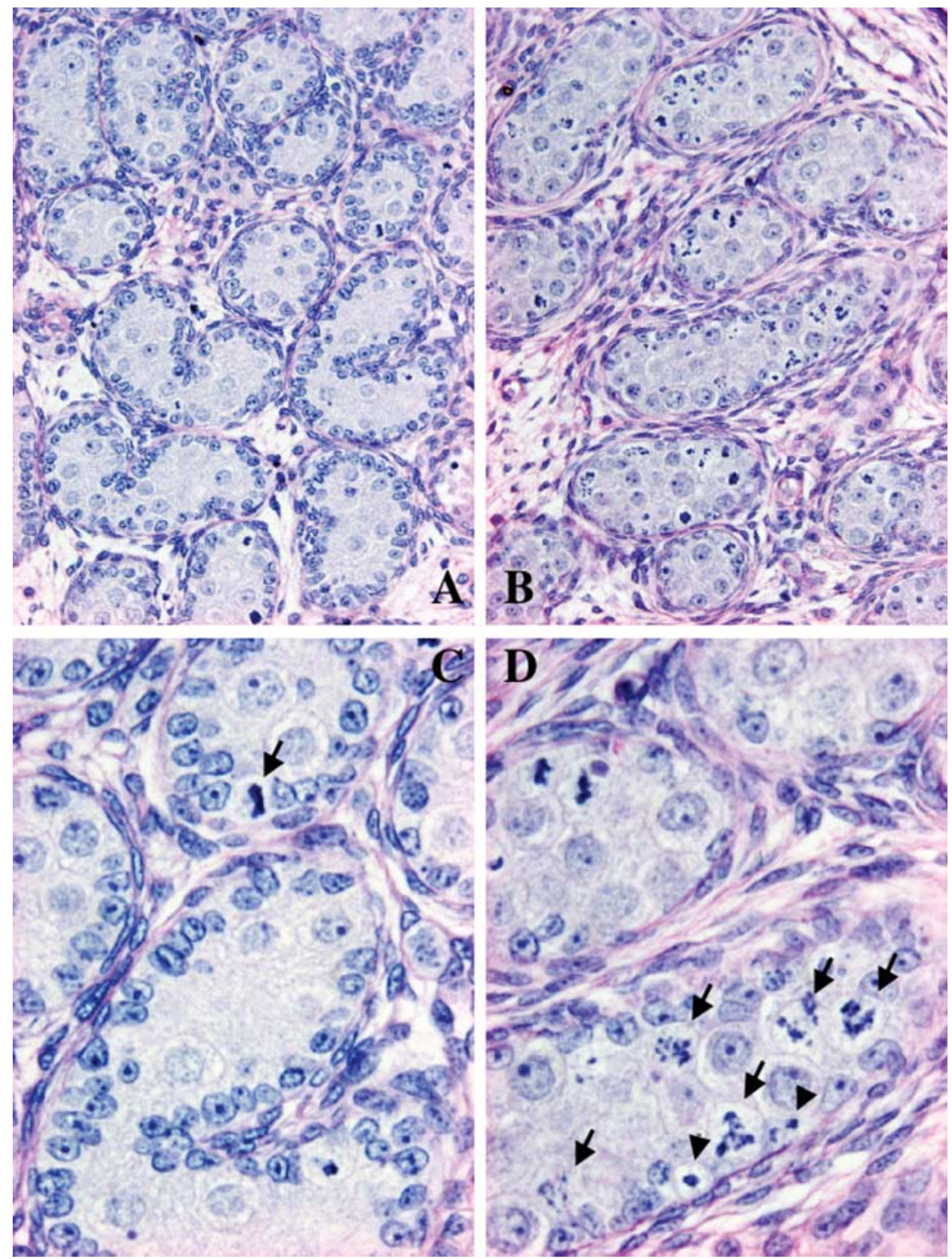

Figure 5 Periodic acid Schiff staining in normal (A and C) and hgn/hgn (B and D) testes at PD 1 (A and B $\times 135, C$ and D $\times 360$ ). In normal testes, Sertoli cells, of which nuclei are uniform in shape, form a palisade distribution along the basement membrane of the seminiferous tubules (A and C). Normal mitotic Sertoli cell was found (C, arrow). In hgn/hgn testes, Sertoli cells fail to form an alignment along the basement membrane because of their small number. The nuclei of most Sertoli cells are irregular, and a number of abnormal mitotic (arrows) and apoptotic (arrowheads) cells are observed (B and D).

testes may not be due to the reduced number of cells expressing Spag5 but may be due to the rapid degradation of abnormal mRNA resulting from its instability, since the expression of abnormal mRNA derived from mutated allele was extremely low in $+/$ hgn testes.

Using a yeast two-hybrid system, rat Spag5 was identified as a protein interacting with the outer dense fiber of sperm tails. Spag5, which has a molecular weight of $200 \mathrm{kDa}$, was shown to be expressed in pachytene spermatocytes and spermatids, indicating its functional role in spermatid morphogenesis in rats (Shao et al. 2001). Although targeted disruption of the mouse Spag5 protein was performed by the same group, they did not find any significant effect on spermatogenesis or fertility (Xue et al. 2002). In contrast, the other two groups independently identified hMAP126 (human), astrin 

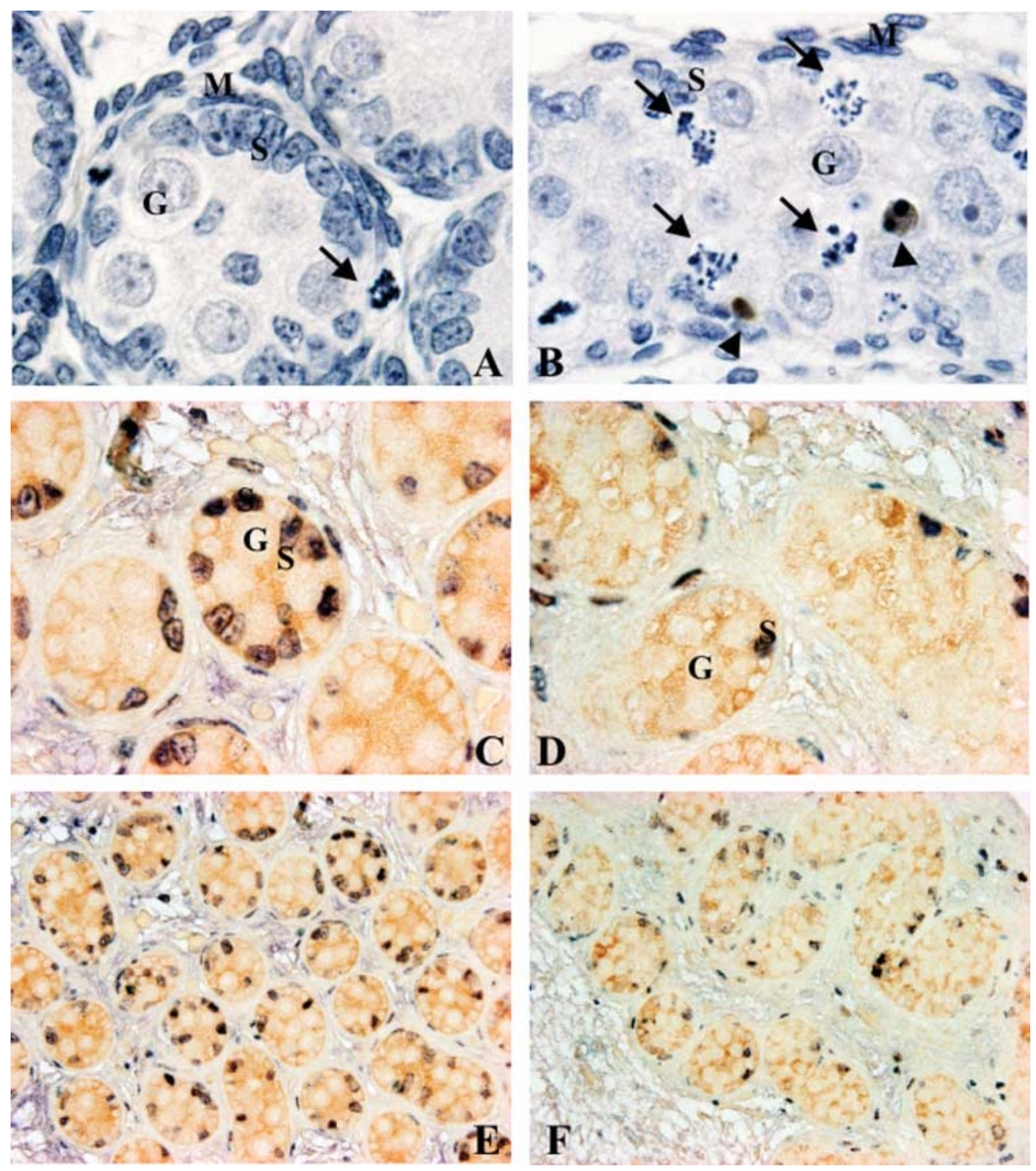

Figure 6 TUNEL staining $(A$ and $B \times 410)$ and immunological detection of BrdU-incorporated Sertoli cells $(C$ and $D \times 260$, $E$ and $F \times 100)$ in normal (A, C, and E) and hgn/hgn (B, D, and F) testes at PD 1. (A and B) TUNEL-positive (arrowheads) and mitotic cells (arrows) were frequently observed in hgn/hgn (B) but not in normal (A) seminiferous tubules. Compared with the normal mitosis observed in normal testes (A), the abnormal mitotic cells in hgn/hgn testes had more abundant cytoplasm containing diffuse chromosomes. (C-F) BrdU-incorporated nuclei were stained blue, and the MIS positive-cytoplasm of Sertoli cells were stained brown. BrdU is incorporated in Sertoli cells but not in gonocytes in both normal and hgn/hgn seminiferous tubules (C and D). There were fewer BrdU-positive Sertoli cells in hgn/hgn (F) than in normal (E) testes. G, gonocyte; S, Sertoli cell; $M$, myoid cell.

(human), and mastrin (mouse), all of which have amino acid sequences similar to that of Deepest and have a molecular weight of around $130 \mathrm{kDa}$, and these proteins were co-localized with the spindle apparatus in mitotic cells (Chang et al. 2001, 2003; Mack \& Compton, 2001). Astrin has been found to be expressed in various organs and essential for mitosis progression, since silencing of astrin in HeLa cells by RNA interference resulted in mitotic arrest with formation of multipolar and highly disordered spindles (Gruber et al. 2002). Since, at present, the gene encoding MAP126, astrin, and Deepest has been mapped to the Spag5 locus in the NCBI genome database (Map Viewer, NCBI, World Wide
Web), there is an obvious discrepancy between the results of knockout mice and RNA interference. In mouse, Spag5 is composed of 24 exons, distributed over $24 \mathrm{~kb}$ of the genome in mouse (Chang et al. 2003). Although deleting a $0.7 \mathrm{~kb}$ genomic fragment containing the first exon of mouse Spag5 extinguished a $200 \mathrm{kDa}$ protein, two peptides ( 125 and $150 \mathrm{kDa}$ ) immunologically detectable with anti-Spag 5 antibody were present in the knockout mice (Xue et al. 2002). Recently, the same group has reported that rat Spag5, expected as an astrin orthologue, is expressed in various tissues and that rat testis contains several Spag5 proteins with different molecular weights (Fitzgerald et al. 2006). Based on this 

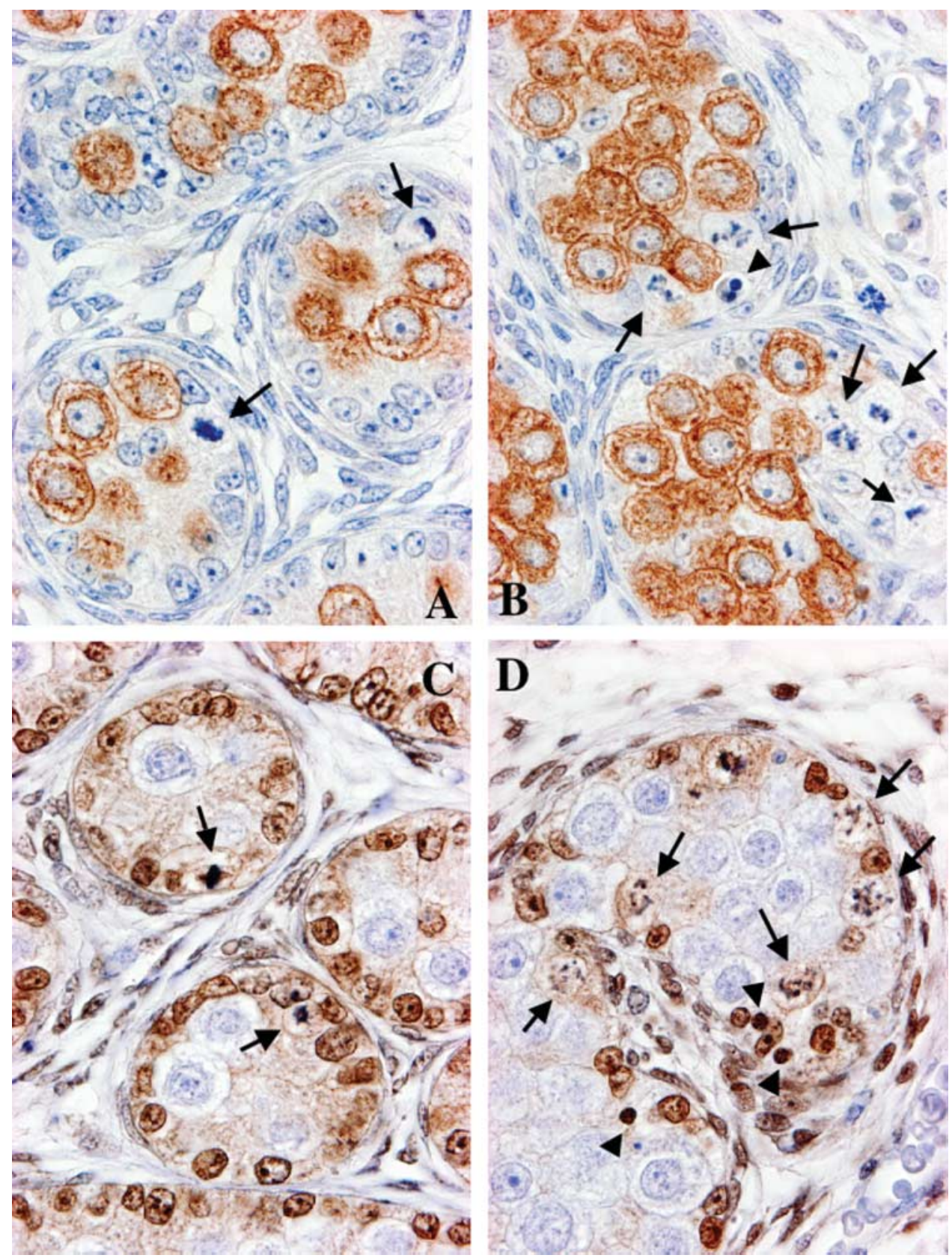

Figure 7 Identification of mitotic and apoptotic cells in the seminiferous tubules of normal (A and C) and hgn/hgn (B and D) rats at PD 1. Tissue samples were immunostained for the germ cell-specific marker VASA (A and B) and for the Sertoli cell-specific marker GATA-4 (C and D) ( $\times 360)$. Sertoli cells were negative for VASA, but positive for GATA-4, whereas gonocytes were positive for VASA, but negative for GATA-4. Mitotic cells in the seminiferous tubules of normal testes (arrows) were positive for Sertoli cell-specific markers (C). Cells showing abnormal mitotic metaphase (arrows) and apoptosis (arrowheads) were negative for VASA, but positive for GATA-4 (B and D).

situation, they mentioned the possibility that particular knockout event did not extinguish all functionality of Spag5 proteins (Fitzgerald et al. 2006).

Our findings indicate that rat hypogonadism ( $h g n / h g n)$ is involved in a mutation in the Spag5 gene. This gene was located in the appropriate chromosomal region restricted by our fine linkage mapping. The molecular weight of rat Spag5 protein predicted by our RACE-PCR is estimated to be a $132 \mathrm{kDa}$, which is comparable with that of human astrin (Mack \& Compton 2001), but not with 200 kDa of rat Spag5 (Shao et al. 2001). Moreover, the 25 bp insertion present in the first coiled-coil domain of Spag 5 was found to result in a truncated protein lacking the primary spindletargeting domain at the $\mathrm{C}$ terminus (Mack \& Compton 2001). The hgn mutation, therefore, might lose the Spag5 function as a microtubule-associated protein. If we consider the functional importance of microtubules and its associated proteins in cell proliferation and 

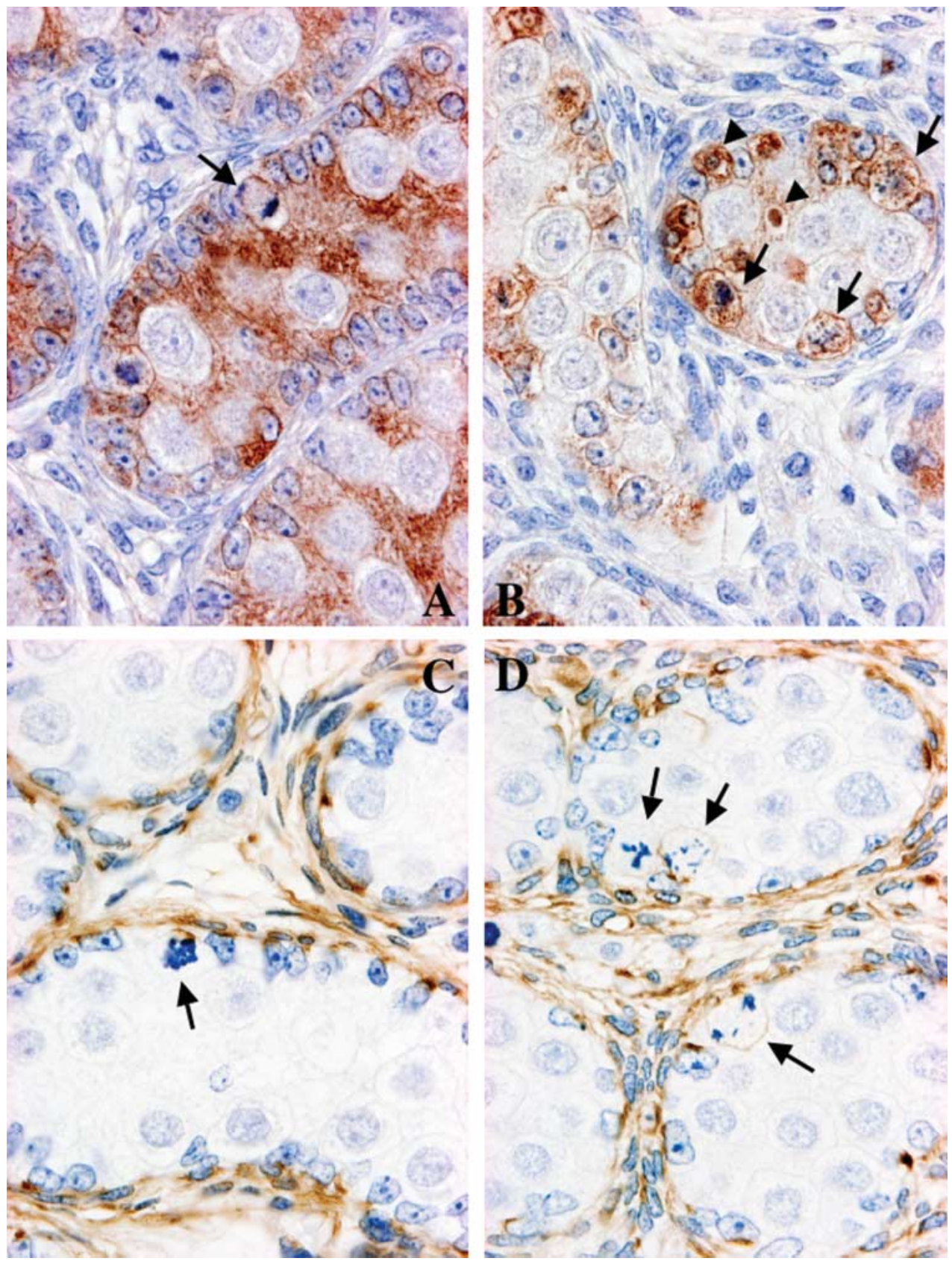

Figure 8 Identification of mitotic and apoptotic cells in the seminiferous tubules of normal (A and C) and hgn/hgn (B and D) rats at PD 1 (A and B) and PD 0 (C and D). Tissue samples were immunostained for the Sertoli cell-specific marker MIS (A and B) and for the somatic cell-specific marker VM (C and D) ( $\times 360)$. Sertoli cells were positive for MIS and VM, whereas gonocytes were negative for the markers. Mitotic cells in the seminiferous tubules of normal testes (arrows) were positive for MIS and VM (A and C). Cells showing abnormal mitotic metaphase (arrows) and apoptosis (arrowheads) were positive for MIS (B). In the apoptotic Sertoli cells, VM is located in their cell membranes (D, arrows).

differentiation, it is reasonable that the hgn phenotype involving defective cell mitosis and increased apoptosis (Suzuki et al. 2004b, Yagi et al. 2006) would be caused by the mutation in the Spag5 gene. Although, at present, it is unclear why Spag5 knockout mice have a normal phenotype, one of the possibilities is that the discrepancy between the $h g n / h g n$ rats and the knockout mice may be due to the types of mutations. In hgn/hgn rats, since the insertion mutation causes a frame-shift mutation, leading to the insertion of a stop codon, the Spag 5 protein is truncated and subsequent degraded. If the downstream sequence containing coiled-coil domain is shared with the variants, the compensation of function is not expected. Further investigations are required to reveal this possibility and the species differences in the requirement of functional Spag5. 
We also provide pathological evidence supporting that the hgn phenotype is caused by deletion of Spag 5 function. In hgn/hgn testes of PD 1 rats, we often found abnormal mitotic metaphase cells with large amounts of cytoplasm. Previously, we suspected that these cells were abnormal gonocytes that failed to undergo mitotic arrest (Suzuki et al. 1993, 2004b). However, our immunohistochemical results have shown that these mitotic metaphase cells are Sertoli cells, since they are positive for GATA-4, MIS, and VM but negative for VASA. The defects in mitosis of Sertoli cells of hgn/hgn rats have features analogous to in vitro mitotic arrest in HeLa cells caused by Spag5 RNA interference (Gruber et al. 2002). Low-mitotic activity in Sertoli cells of $h g n / h g n$ testes, as shown by the low level of BrdU incorporation, indicates that increased abnormal mitosis is not accompanied by increased S-phase DNA synthesis, suggesting mitotic arrest or a prolonged period of mitotic metaphase. In addition, the dispersed distribution of chromosomes observed in mitotic Sertoli cells in hgn/hgn testes suggests the presence of disordered spindles. These abnormal mitotic cells are not thought to progress through the cell cycle by passing through mitotic checkpoints (Gruber et al. 2002). In agreement with findings in Spag5 deficient-HeLa cells, we found that, in hgn/hgn testes, a considerable number of Sertoli cells undergo apoptotic cell death (Suzuki et al. 2004b, Yagi et al. 2006). These histological features suggest that the testicular phenotype in hgn/hgn rats is caused by a loss of Spag 5 function and that these effects appear predominantly in proliferating Sertoli cells. In hgn/hgn males, most of gonocytes fail to differentiate into spermatonogia and are likely to have degenerated before entering meiosis. Transplantation of $h g n / h g n$ gonocyte into normal testis may be informative to know whether the Spag5 mutation directly affect the germ cells development.

Fitzgerald and colleagues have reported that the preparation from rat total testis contains several Spag5 proteins with different molecular weights $(200,130,110$, 58 , and $31 \mathrm{kDa})$. Although $58 \mathrm{kDa}$ Spag 5 protein has been localized in sperm tail, other Spag 5 proteins such as $130 \mathrm{kDa}$ Spag5, which is recognized by anti-astrin antibodies and may be similar to $134 \mathrm{kDa}$ human astrin, is absent from spermatids and sperm (Fitzgerald et al. 2006). Although other Spag5 proteins and astrin have not yet been localized in testicular sections, which may be due to the low level of immunostaining with the antibody used (Shao et al. 2001, Chang et al. 2003), it is reasonable to consider that testicular somatic cells also express Spag5 proteins (Fitzgerald et al. 2006). In our preliminary experiments, we detected a low level of defective Spag5 mRNA expression in adult hgn/hgn testes (data not shown), which has no spermatogenesis (Suzuki et al. 2004b), suggesting that testicular somatic cells express Spag5 mRNA. In hgn/hgn rats, differentiation or maturation is defective in all testicular cell types during postnatal development. To distinguish the direct effect of Spag5 mutation in other testicular cell types from the secondary effects caused by Sertoli cell dysfunction, it is necessary to show the spatial and temporal expression of Spag5 in developing testes. Our observation of abnormal mitotic metaphase and apoptosis in postnatal Sertoli cells of hgn/hgn testes indicates that Spag5 may be expressed in Sertoli cells or that Sertoli cells are most sensitive to the loss of Spag5 function. Spag 5 may be involved in the synchronization of active proliferation and differentiation of Sertoli cells during the early postnatal period. Premature Sertoli cell must develop a large cytoplasm to support the considerable number of germ cells at various stages of differentiation during adulthoods (Sharpe et al. 2003). This might cause subtle instability in chromosome distribution during mitosis progression. Furthermore, Spag5, which has a role in microtubule stabilization, is also expressed in interphase cells (Mack \& Compton 2001, Fitzgerald et al. 2006). Microtubules are important for cytoskeletal networks as well as for the formation of mitotic spindles. Sertoli cells have an abundant amount of microtubule networks, which are involved in structural maintenance and polarization (Redenbach \& Boekelheide 1994). Therefore, the deletion of Spag5 may affect the physiological function of these microtubules.

Our RT-PCR experiments (data not shown) and gene expression data from NCBI (Map Viewer, NCBI, World Wide Web) indicate that Spag 5 mRNA is expressed in various embryonic tissues. In addition to severe testicular dysplasia, hgn/hgn rats show renal hypoplasia, ovarian hypoplasia, and growth retardation (Suzuki et al. 1991, 1992), all of which are detected by ED 16.5 (data not shown). Therefore, the Spag 5 defect may affect many cell types during early stages of embryonic development, and it may have different degrees of effects on cell types during organogenesis. To reveal the physiological function of Spag5 in the embryonic development of ovaries, kidneys, and other organs, it is necessary to characterize cell mitosis and apoptosis in the embryonic pathogenesis of the hypoplastic organs in hgn/hgn rats. Basic research into the molecular events of the cell cycle is important for our understanding of embryonic development as well as for identifying target molecules to prevent cancer growth. Many proteins participating in the progression of mitosis have been identified in yeast, and RNA interference has been used to determine gene function during mammalian cell mitosis. There have been few animal models, however, showing the molecular events associated with defects in mitosis progression. To date there has been no other animal model in which the deletion of a MAP results in a defect of mitosis progression. The results presented here suggest that Spag5 is involved in the in vivo mitosis progression of Sertoli cells and that the hgn/hgn rat is a unique animal model for studying the function of Spag5. In addition, although the basic machinery responsible for 
mitosis progression is considered to be common in most eukaryotes, mitosis progression in mammalian cells, which have a large diversity in size and shape, might require additional factors, such as Spag5.

\section{Acknowledgements}

This work was supported in part by a Grant-in-Aid from Ministry of the Environment of Japan. We thank all those who worked in our laboratory for their time-consuming efforts to maintain the mutant strains.

\section{References}

Chang MS, Huang CJ, Chen ML, Chen ST, Fan CC, Chu JM, Lin WC \& Yang YC 2001 Cloning and characterization of hMAP126, a new member of mitotic spindle-associated proteins. Biochemical and Biophysical Research Communications 287 116-121.

Chang MS, Chen CYa, Huang CJ, Fan CC, Chu JM \& Yang YC 2003 Expression and promoter analysis of mouse mastrin gene. Biochemical and Biophysical Research Communications 307 491-497.

Clermont Y \& Perey B 1957 Quantitative study of the cell population of the seminiferous tubules in immature rats. American Journal of Anatomy 100 241-267.

Fitzgerald CJ, Oko RJ \& Van der Hoorn FA 2006 Rat Spag 5 associates in somatic cells with endoplasmic reticulum and microtubules but in spermatozoa with outer dense fibers. Molecular Reproduction and Development 73 92-100.

Gruber J, Harborth J, Schnabel J, Weber K \& Hatzfeld M 2002 The mitotic-spindle-associated protein astrin is essential for progression through mitosis. Journal of Cell Science 115 4053-4059.

Hakamata Y, Kikukawa K, Kamei T, Suzuki K, Taya K \& Sasamoto S 1988 A new male hypogonadism mutant rat (hgn/hgn): concentrations of testosterone $(\mathrm{T})$, luteinizing hormone $(\mathrm{LH})$, and folliclestimulating hormone $(\mathrm{FSH})$ in the serum and the responsiveness of accessory sex organs to exogenous T, FSH, human chorionic gonadotropin, and luteinizing hormone-releasing hormone. Biology of Reproduction 38 1145-1153.

Hamada T, Tashiro K, Tada H, Inazawa J, Shirozu M, Shibahara K, Nakamura T, Martina N, Nakano T \& Honjo T 1996 Isolation and characterization of a novel secretory protein, stromal cell- derived factor-2 (SDF-2) using the signal sequence trap method. Gene $\mathbf{1 7 6}$ 211-214.

Ketola I, Rahman N, Toppari J, Bielinska M, Porter-Tinge SB, Tapanainen JS, Huhtaniemi IT, Wilson DB \& Heikinheimo M 1999 Expression and regulation of transcription factors GATA-4 and GATA-6 in developing mouse testis. Endocrinology 140 1470-1480.

Kobayashi A, Higashide T, Hamasaki D, Kubota S, Sakuma H, An W, Fujimaki T, McLaren MJ, Weleber RG \& Inana G 2000 HRG4 (Unc119) mutation found in cone-rod dystrophy causes retinal degeneration in at transgenic model. Investigative Ophthalmology and Visual Science 41 3268-3277.

Kukita A, Mukai T, Miyata T \& Hori K 1988 The structure of brainspecific rat aldolase $\mathrm{C}$ mRNA and the evolution of aldolase isozyme genes. European Journal of Biochemistry 171 471-478.

Kuroda T, Lee MM, Haqq CM, Powell DM, Manganaro TF \& Donahoe PK 1990 Mullerian inhibiting substance ontogeny and its modulation by follicle-stimulating hormone in the rat testes. Endocrinology 127 1825-1832.

Mack GJ \& Compton DA 2001 Analysis of mitotic microtubuleassociated proteins using mass spectrometry identifies astrin, a spindle-associated protein. PNAS 98 14434-14439.

Ohishi K, Inoue N \& Kinoshita T 2001 PIG-S and PIG-T, essential for GPI anchor attachment to proteins, from a complex with GAA1 and GPI8. EMBO Journal 20 4088-4098.
Paranko J, Kallajoki M, Pelliniemi LJ, Lehto VP \& Virtanen I 1986 Transient coexpression of cytokeratin and vimentin in differentiating rat Sertoli cells. Developmental Biology 117 35-44.

Redenbach DM \& Boekelheide K 1994 Microtubules are oriented with their minus-ends directed apically before tight junction formation in rat Sertoli cells. European Journal of Cell Biology 65 246-257.

Segre JA, Nemhauser JL, Taylor BA, Nadeau JH \& Lander ES 1995 Positional cloning of the nude locus: genetic, physical, and transcription maps of the region and mutations in the mouse and rat. Genomics 28 549-559.

Shao X, Xue J \& Van der Hoorn FA 2001 Testicular protein Spag5 has similarity to mitotic spindle protein Deepest and binds outer dense fiber protein Odf1. Molecular Reproduction and Development 59 410-416.

Sharpe RM, McKinnell C, Kivlin C \& Fisher JS 2003 Proliferation and functional maturation of Sertoli cells, and their relevance to disorders of testis function in adulthood. Reproduction 125 769-784.

Sugihara H, Hattori T \& Fukuda M 1986 Immunohistochemical detection of bromodeoxyuridine in formalin-fixed tissues. Histochemistry 85 193-195.

Suzuki H \& Suzuki K 1995 Pathophysiology and postnatal pathogenesis of hypoplastic kidney (hpk/hpk) in the male hypogonadic mutant rat (hgn/hgn). Journal of Veterinary Medical Science 57 891-897.

Suzuki H \& Suzuki K 1998 Rat hypoplastic kidney (hpk/hpk) induces renal anemia, hyperparathyroidism, and osteodystrophy at the end stage of renal failure. Journal of Veterinary Medical Science $\mathbf{6 0}$ 1051-1058.

Suzuki H, Hakamata Y, Kamei T, Kikukawa K \& Suzuki K 1992 Reproduced fertility in female homozygotes for hgn (male hypogonadism) selected by hgn-associated hypoplastic kidney. Congenital Anomalies Kyoto 32 167-178.

Suzuki H, Inaba M \& Suzuki K 1998 Temporal and spatial distribution of alkaline phosphatase activity in male hypogonadic rat (hgn/hgn) testis during postnatal development. Journal of Veterinary Medical Science $60671-679$.

Suzuki H, Kokado M, Saito K, Kunieda T \& Suzuki K 1999 A locus responsible for hypogonadism (hgn) is located on rat chromosome 10. Mammalian Genome 10 1106-1107.

Suzuki H, Fukaya S, Saito K \& Suzuki K 2000 A locus responsible for osteochondrodysplasia (ocd) is located on rat chromosome 11. Mammalian Genome 11 464-465.

Suzuki H, Nakamiya E, Daigo K, Saito K \& Suzuki K 2004a Fine mapping of the region including hypogonadism (hgn) locus on rat chromosome 10. Journal of Veterinary Medical Science $\mathbf{6 6}$ 1151-1154.

Suzuki H, Yagi M, Saito K \& Suzuki K $2004 b$ Dysplastic development of seminiferous tubules and interstitial tissue in rat hypogonadic (hgn/hgn) testes. Biology of Reproduction 71 104-116.

Suzuki H, Tokuriki T, Saito K, Hishida A \& Suzuki K 2005 Glomerular hyperfiltration and hypertrophy in the rat hypoplastic kidney as a model of oligomeganephronic disease. Nephrology Dialysis and Transplantation 20 1362-1369.

Suzuki H, Tokuriki T, Kamita H, Oota C, Takasu M, Saito K \& Suzuki K 2006 Age-related pathophysiological changes in rat oligomeganephronic hypoplastic kidney. Pediatric Nephrology [in press].

Suzuki K, Hashimoto S, Imamichi T, Uchino T \& Motoyoshi S 1987 Differential diagnosis of hydronephrosis types I and II in rats by echography. Nippon Juigaku Zasshi 49 543-546.

Suzuki K, Hakamata Y, Hamada A, Kikukawa K \& Wada MY 1988 Imamichi T: Male hypogonadism as a candidate of deficiency of postnatal testicular growth or differentiating factor(s): a new autosomal recessive mutation in the rat. Journal of Heredity $\mathbf{7 9}$ $54-58$.

Suzuki K, Suzuki H, Hakamata Y, Kamei K \& Kikukawa K 1991 Genetic analysis and histology of hypoplastic kidneys in the male hypogonadic mutant (hgn/hgn) rat. Congenital Anomalies Kyoto 31 305-314. 
Suzuki K, Hakamata Y, Suzuki H, Taya K \& Sasamoto S 1993 Postnatal alterations of testicular morphology, testicular testosterone contents and plasma hormone levels in male hypogonadic rat (hgn/hgn). Journal of Reproduction and Development 39 333-346.

Toyooka Y, Tsunekawa N, Takahashi Y, Matsui Y, Satoh M \& Noce T 2000 Expression and intracellular localization of mouse Vasa-homologue protein during germ cell development. Mechanism of Development 93 139-149.

Xue J, Tarnasky HA, Rancourt DE \& Van der Hoorn FA 2002 Targeted disruption of the testicular SPAG5/deepest protein does not affect spermatogenesis or fertility. Molecular Cell Biology 22 1993-1997.
Yagi M, Suzuki H \& Suzuki K 2006 Apoptotic Sertoli cell death in rat hypogonadic testes during early postnatal development. Asian Journal of Andrology [in press].

Received 12 January 2006

First decision 13 March 2006

Revised manuscript received 30 March 2006

Accepted 24 April 2006 